\title{
Matrilysin (MMP-7) degrades VE-cadherin and accelerates accumulation of beta-catenin in the nucleus of human umbilical vein endothelial cells
}

\author{
YASUSHI ICHIKAWA, TAKASHI ISHIKAWA, NOBUYOSHI MOMIYAMA, MASAKO KAMIYAMA, \\ HARUMI SAKURADA, RYUSEI MATSUYAMA, SATOSHI HASEGAWA, TAKASHI CHISHIMA, \\ YOHEI HAMAGUCHI, SHOICHI FUJII, SHUJI SAITO, KAORI KUBOTA, SHINGO HASEGAWA, \\ HIDEYUKI IKE, SHIGEO OKI and HIROSHI SHIMADA
}

Department of Gastroenterological Surgery, Yokohama City University Graduate School of Medicine, Japan

Received February 21, 2005; Accepted May 26, 2005

\begin{abstract}
Matrilysin, MMP-7, is an important target for antimetastasis therapy of colorectal cancer because it is a strong proteolytic factor secreted from the cancer cell itself and it induces tumor angiogenesis. In a previous report, we showed that matrilysin accelerated human umbilical vein endothelial cell (HUVEC) proliferation in low serum conditioned medium. In the present study, we show that matrilysin stimulation decreased VE-cadherin expression, induced accumulation of beta-catenin in the nucleus of the HUVEC, and up-regulated matrilysin mRNA expression. These results compel a hypothesis that matrilysin cleaves VE-cadherin and releases beta-catenin from the VE-cadherin/catenin complex; the free beta-catenin can activate T-cell factor (Tcf) DNA binding protein, which accelerates cell proliferation and matrilysin expression.
\end{abstract}

\section{Introduction}

In previous reports, we have proposed that matrilysin, MMP-7, plays important roles in colon cancer invasion $(1,2)$ and is a promising target for suppression of colon cancer metastasis (3). We reported that matrilysin induced growth acceleration of endothelial cells (4) and anti-matrilysin therapy inhibited tumor angiogenesis (5). It has been suggested that angiogenesis requires a matrix-degrading enzyme such as gelatinase A or B (6), or tissue plasminogen activator (7), and that the main reason for cancer suppression by matrix metalloproteinases (MMP) inhibitors was their antiangiogenic effect (8). The role of proteinases in angiogenesis is considered to be degradation of surrounding tissue to make

Correspondence to: Dr Yasushi Ichikawa, Department of Surgery-2, Yokohama City University School of Medicine, 3-9 Fukuura, Kanazawa-ku, Yokohama 236-0004, Japan

E-mail: yasu0514@med.yokoham-cu.ac.jp

Key words: VE-cadherin, beta-catenin space for newly sprouting blood vessels. However, recently it has been shown that certain proteinases exhibit interesting properties relative to cell proliferation. In particularly, matrilysin was reported to stimulate the Tcf DNA promoter which accelerates cell proliferation through Wnt signal transduction, by degradation of cadherin on the surface of the cell membrane and release of beta-catenin. Thus, the degradation of tissue may be considered as destruction of tissue for invasion or remodelling of tissue construction, and also as the first stimulus of signal transduction originating on the surface of the cell membrane.

In the present study, we show that matrilysin, accelerated the proliferation of human umbilical endothelial cells (HUVECs), degraded VE-cadherin on the surface of HUVECs, and led to an accumulation of beta-catenin in the nucleus of the HUVECs.

\section{Materials and methods}

Cells and reagents. HUVECs were obtained from Clonetics (San Diego, CA). Type I and type IV collagen, MCDB131, Dulbecco's Modified Eagle's Medium (DMEM), human endothelial serum-free medium (SFM), 10\% heat-inactivated fetal bovine serum (FBS), penicillin/streptomycin $(100 \mathrm{IU} / \mathrm{ml})$, recombinant endothelial growth factor (rEGF), heparin, bovine pituitary extract (BPE), and human plasma fibronectin were obtained from Gibco BRL (Island, NY). Human recombinant MMP-7 (rMMP-7) was provided by Oriental Yeast Co. Ltd. (Tokyo, Japan). Quantikine ${ }^{\circledR}$ Antihuman VE-cadherin antibody was obtained from Chemicon International Inc. (Temecula, CA), and anti-human beta catenin antibody was from Sigma (St Louis, MO).

Cell culture. As previously described (4), HUVECs were cultured in MCDB131 or human endothelial SFM supplemented with $10 \%$ heat inactivated FBS, $100 \mathrm{IU} / \mathrm{ml}$ penicillin/streptomycin, $10 \mu \mathrm{g} / \mathrm{ml}$ heparin, $10 \mu \mathrm{g} / \mathrm{ml} \mathrm{BPE}$, and $5 \mu \mathrm{g} / \mathrm{ml} \mathrm{rEGF}$ in a humidified atmosphere of $95 \%$ air and $5 \% \mathrm{CO}_{2}$ at $37^{\circ} \mathrm{C}$. Cells were cultured on plates coated with $0.003 \%$ type IV collagen, and were used between passages 2 and 5 . 
Stimulation by $r M M P-7$. Cells $\left(1 \times 10^{5}\right)$ were cultured in the medium with $2 \%$ FBS at a final concentration of 0.5 or $1 \mu \mathrm{g} / \mathrm{ml}$ of rMMP-7. This concentration of MMP-7 was previously shown to be effective in accelerating the proliferation of HUVECs in a culture dish of $35 \mathrm{~mm}$ in diameter (4). Forty-eight and $72 \mathrm{~h}$ after the addition of rMMP-7, cells were counted $(n=5)$. HUVECs were collected by a cell-scraper and used for Western blotting of VE-cadherin, and reverse-transcriptionpolymerase chain reaction (RT-PCR) of matrilysin. Control cells were cultured in the same medium without the addition of rMMP-7.

In this study, the number of HUVECs at the beginning of the culture was $1 \times 10^{5}$ cells per $35 \mathrm{~mm}$ culture dish, and cells did not reach confluence during the time course of the experiment.

Western. HUVECs were collected using a scraper at various times after rMMP-7 stimulation, were washed with ice-cold phosphate buffered saline (PBS), and dissolved in lysis buffer (50 mM HEPES, pH 7.0, $150 \mathrm{mM} \mathrm{NaCl,} \mathrm{10 \%} \mathrm{glycerol,}$ $1.2 \%$ Triton $\mathrm{X}-100,1.5 \mathrm{mM} \mathrm{MgCl}_{2}, 1 \mathrm{mM}$ EGTA, aprotinin, leupeptin, PMSF, and $1 \mathrm{mM} \mathrm{Na}_{3} \mathrm{VO}_{4}$ ). The protein lysates were centrifuged at $12000 \mathrm{rpm}$ for $10 \mathrm{~min}$ at $4^{\circ} \mathrm{C}$. The samples were mixed with 2x Sample buffer (125 mM Tris- $\mathrm{HCl}, \mathrm{pH} 6.75$, $4 \%$ SDS, $20 \%$ glycerol, $0.002 \%$ bromophenol blue, $10 \%$ 2-mercaptoethanol), boiled for $5 \mathrm{~min}$, and subjected to sodium dodecyl sulfate (SDS)-polyacrylamide gel electrophoresis (7.5\% SDS-PAGE). After SDS-PAGE, the gels were transferred to $0.45 \mu \mathrm{m}$ nitrocellulose membrane (Bio-Rad Laboratories, CA). The membranes were blocked with TBS-Tween 20 (20 mM Tris- $\mathrm{HCl}, \mathrm{pH} 7.4,136 \mathrm{mM} \mathrm{NaCl}$, $2 \mathrm{mM} \mathrm{KCl}$, and $0.2 \%$ Tween 20) containing $0.5 \%$ skimmed milk for $1 \mathrm{~h}$ at room temperature, and then reacted with anti-human VE-cadherin antibody at $4{ }^{\circ} \mathrm{C}$ overnight, followed by incubation with horseradish peroxidase linked anti-mouse Ig whole antibody 1:1000 (Amersham Life Science, Buckinghamshire, England) for $30 \mathrm{~min}$ at room temperature. Protein bands were visualized by the ECL detection system (Amersham Life Science). Western blot analysis was performed for culture medium of HUVECs, with or without matrilysin, to detect cleaved VE-cadherin.

Immunohistochemistry. For localization of beta-catenin in HUVECs, immunostaining of beta-catenin was performed. HUVECs were cultured and stimulated by rMMP-7, as described above, in a Lab-Tek II chamber (Nalge Nunc International, Rochester, NY). At various times after rMMP-7 stimulation, a HUVEC on a cell was picked up and fixed by formalin. Immunohistochemistry was performed using a commercial kit according to the manufacturer's instructions (Histofine SAB-PO (R) kit, Nichirei, Tokyo, Japan), with the following modifications. The sections were incubated with the primary anti-human beta-catenin antibody overnight at $4{ }^{\circ} \mathrm{C}$. A positive reaction was visualized by incubation of the slide with stable 3,3'-diaminobenzidine for 5-10 min (Wako, Osaka, Japan), and counterstained with methyl green.

$R T$-PCR. RT-PCR was performed as previously described (4). Briefly, HUVECs were collected by a cell-scraper at various intervals after rMMP-7 stimulation, and mRNA was extracted

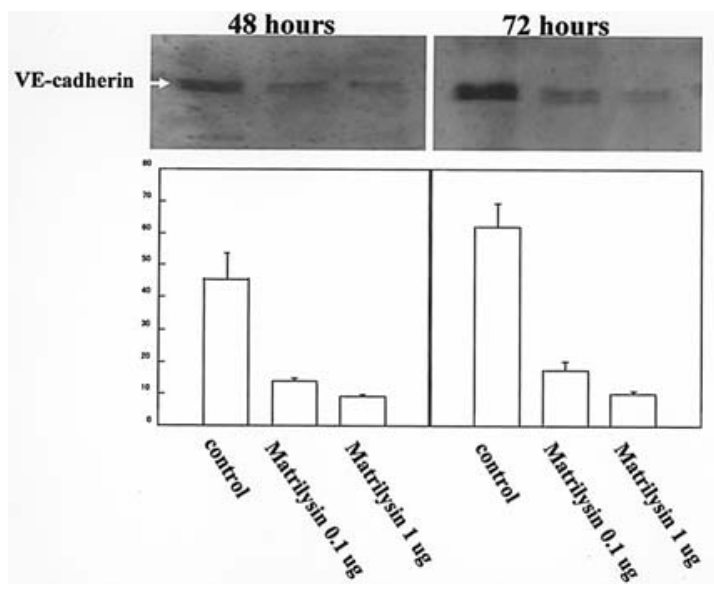

Figure 1. Western blot analysis, using anti-human-VE-cadherin antibody to HUVEC cell lysate of 48 and $72 \mathrm{~h}$ incubation with 0.1 or $1 \mu \mathrm{g} / \mathrm{ml}$ matrilysin or control vehicle. VE-cadherin expressed in the HUVECs stimulated by 0.1 or $1 \mu \mathrm{g} / \mathrm{ml}$ of rMMP-7 was significantly attenuated compared with the control (48 h: $45.7+8.1,72 \mathrm{~h}: 62+7.5$ densitometer unit) on both the 48 $(0.1 \mu \mathrm{g} / \mathrm{ml}: 14+1,1 \mu \mathrm{g} / \mathrm{ml}: 9.3+0.58)$ and $72 \mathrm{~h}(0.1: 17.7+2.5,1: 10+1)$ after stimulation.

by the acid-guanidium thiochyanate-phenol-chloroform method. Reverse-transcribed cDNA was amplified by polymerase chain reaction (PCR) using a thermal cycler (PerkinElmer/Cetus, Norwalk, CT).

PCR was performed for matrilysin (sense primer sequence: 5'-TCTTTGGCCTACCTATAACTGG-3', antisense: 5'CTAGACTGCTACCATCCGTC-3'), cyclooxigenase-2 (COX-2; sense: 5'-TGTTTGCAAGCAGGACTTTG-3', antisense: 5'-CCTTCCGGTGTGAAACATCT-3') and cyclin D1 (sense: 5'-CAGCACTTCACGCATCAGTT-3', antisense: 5'-CAGCAAACCGTAGATGCTCA-3'), which had promoter lesions stimulated by Tcf.

\section{Results}

As shown previously (4), HUVECs stimulated by 0.1 or $1 \mu \mathrm{g} / \mathrm{ml}$ of rMMP-7 in low FBS medium showed significant acceleration of cell proliferation compared with controls.

VE-cadherin expressed on HUVECs. VE-cadherin expressed in HUVECs stimulated by 0.1 or $1 \mu \mathrm{g} / \mathrm{ml}$ of $\mathrm{rMMP}-7$ was significantly lower for both $48(0.1 \mu \mathrm{g} / \mathrm{ml}: 14 \pm 1$ densitometer units, $1 \mu \mathrm{g} / \mathrm{ml}: 9.3 \pm 0.58)$ and $72 \mathrm{~h}(0.1 \mu \mathrm{g} / \mathrm{ml}: 17.7 \pm 2.5$, $1 \mu \mathrm{g} / \mathrm{ml}: 10 \pm 1$ ) time points following stimulation compared

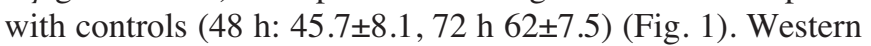
blot analysis for culture medium of HUVECs stimulated by matrilysin showed smaller bands compared with original VE-cadherin (Fig. 2).

Immunostaining of beta-catenin. In the control samples corresponding to 48 and $72 \mathrm{~h}$, beta-catenin mainly located on the cell membrane of HUVECs, and the nuclei were not stained (Fig. 3, left panel). However, beta-catenin staining in the cell membrane at 48 and $72 \mathrm{~h}$ after stimulation with 0.1 or $1 \mu \mathrm{g} / \mathrm{ml}$ of rMMP-7, was weaker than that of the controls, and moreover, the nuclei were stained by anti-beta-catenin antibody (Fig. 3, right panel). 


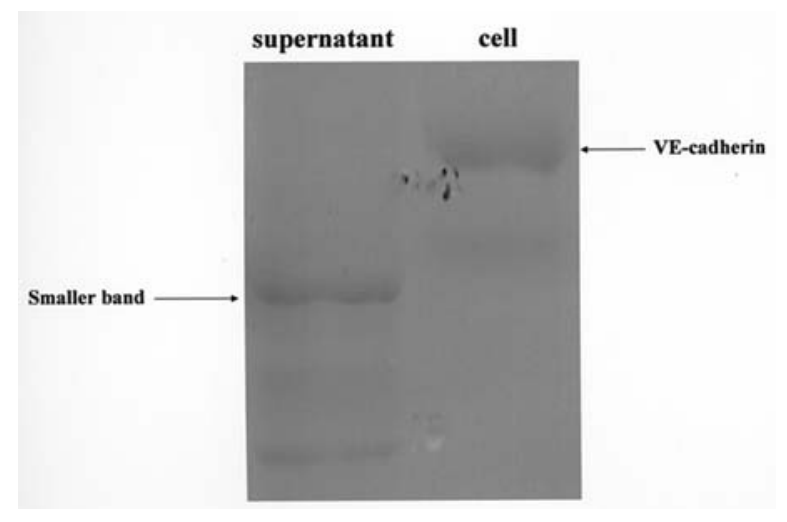

Figure 2. Western blot analysis, using anti-human-VE-cadherin antibody to HUVEC cell lysate and conditioned medium of $72 \mathrm{~h}$ incubation with $1 \mathrm{mg} / \mathrm{ml}$ matrilysin. The cell lane shows a faint band of VE-cadherin. However, in the medium lane, a faint smaller band compared to VE-cadherin is displayed.

RT-PCR of matrilysin, cyclin D1 or COX-2. Control samples at 48 and $72 \mathrm{~h}$ did not show matrilysin mRNA expression. However, HUVECs stimulated with rMMP-7 expressed matrilysin mRNA in a dose-dependent manner (Fig. 4). There was no difference of PCR product amplified by the cyclin D1 primer or between the presence and absence of stimulation by matrilysin, because cyclin D1 was expressed strongly even in HUVECs without matrilysin stimulation. However, COX-2 mRNA was more strongly expressed in HUVECs with matrilysin stimulation than in those without matrilysin (Fig. 4).

\section{Discussion}

As we previously reported (4), matrilysin accelerated proliferation of the HUVEC. Here we showed that matrilysin caused a reduction of VE-cadherin expression on HUVECs with a concomitant accumulation of beta-catenin in the nucleus of HUVECs. It is noteworthy that some previous studies have suggested that matrilysin may play an important role in angiogenesis $(9,10)$.

The role of MMPs in angiogenesis has been believed primarily to be the dissolution of the extracellular matrix (11), or fibrinolysis (12), around the endothelial cells, which make a space for sprouting, or a scattering of endothelial cells. A recent report suggested that there might be other interesting contributions of proteinases in angiogenesis, namely stimulation of cell proliferation. This unexpected property of proteinases has been linked to proteinase cleavage of the ectodomain of transmembrane proteins, such as growth factor ligands and receptors (13). Vascular Endothelial Growth Factor 165, an isoform of VEGF, when bound to connective tissue growth factor (CTGF) as an inactive form, was cleaved and activated by MMP-1, 3, 7, and 13 , and showed a strong ability to promote angiogenesis (14). Trypsin, a well-known serine proteinase, cleaved and activated protease-activated receptor-2 (PAR-2), and active PAR-2 mediated vasodilation, plasma protein extravasation, and endothelial cell proliferation, all regarded as essential steps for neovascularization (15). In the present study, the target of cleavage by the proteinase matrilysin is likely to be vascular endothelial cadherin (VE-cadherin)/cadherin-5, an endothelial-specific member of cadherin family, that forms a complex with beta-catenin and stabilizes cell-to-cell adhesion.

Caveda et al reported that VE-cadherin inhibited growth of HUVECs, and trypsin and EDTA treatment of HUVECs abolished the growth inhibition (16). They proposed that the mechanism of the inhibition was possibly related to betacatenin. VE-cadherin, beta-catenin, and a transcription factor, T Cell Factor-4 (Tcf-4), have been suggested to play important roles in endothelial cell proliferation (17).

Beta-catenin is a component of the cadherin adhesion complex and through its association with Tef DNA binding proteins, it regulates the Wnt signal transduction pathway. Mutations in beta-catenin, or deletion of APC (please define APC) which is a scavenger of beta-catenin, leads to an

\section{Beta-catenin staining}

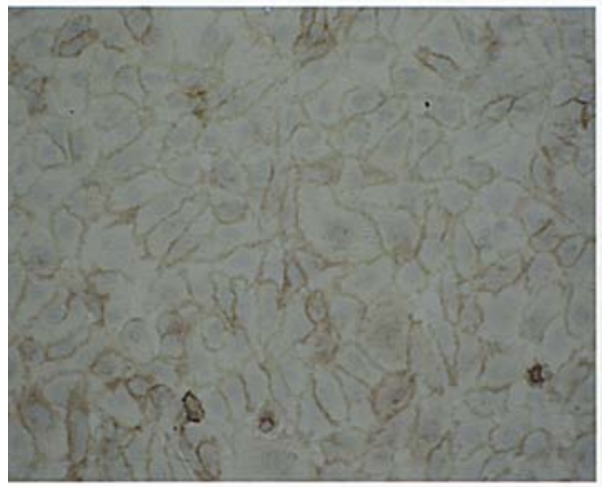

control

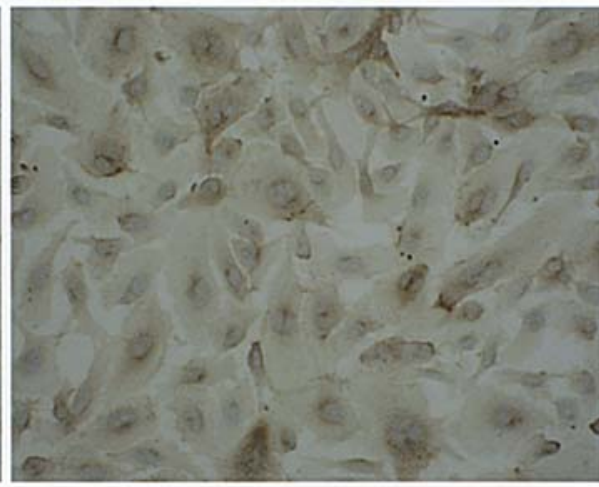

Matrilysin 1ug/ml

Figure 3. Representative results of immunostaining with anti-human-beta-catenin antibody. The left panel is control of $48 \mathrm{~h}$ incubation of a confluent HUVEC, showing that beta-catenin localizes at the cell membrane of the HUVEC and not in the nucleus. The right panel is a HUVEC stimulated by $1 \mu \mathrm{g} / \mathrm{ml}$ of matrilysin, showing beta-catenin identified in the nucleus and not at the cell membrane. 


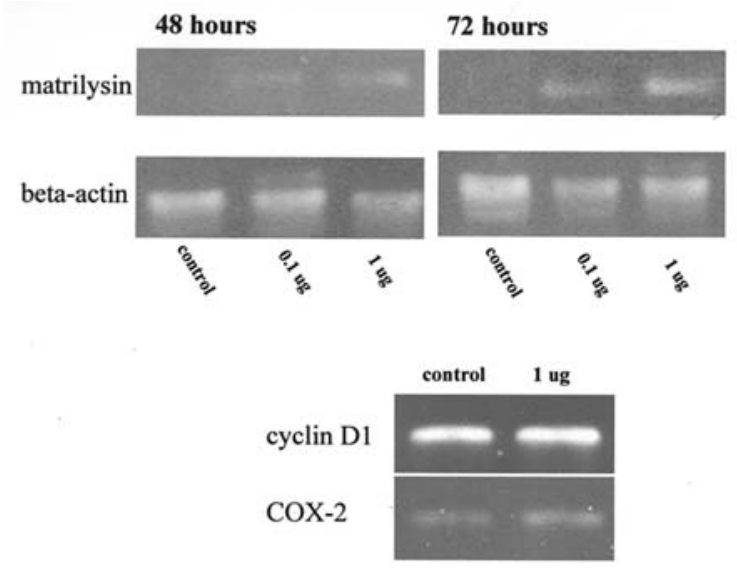

Figure 4. Matrilysin, cyclin D1 or COX-2 mRNA expression of HUVECs analyzed using RT-PCR. Matrilysin mRNA is not expressed in control HUVECs 48 and $72 \mathrm{~h}$ after culture in medium with $2 \%$ FBS. Faint expression of matrilysin could be detected in the HUVEC stimulated 0.1 and $1 \mu \mathrm{g} / \mathrm{ml}$ human recombinant-matrilysin. Cyclin D1 is strongly expressed even in control. There is no difference of cyclin D1 expression between the presence and absence of matrilysin. However, expression of COX-2 mRNA in HUVECs stimulated by matrilysin is apparently stronger than that of control.

accumulation of beta-catenin in cells, activation of Wnt signal transduction, hyper-activation of cell growth, and carcinogenesis in many organs, especially in the colon (18). To activate Tcf DNA binding protein by beta-catenin, accumulated beta-catenin has to be transported into the nucleus. It has been reported that nuclear beta-catenin expression in colon cancer cells, confirmed by immunohistochemistry, was related to malignant activity such as cancer invasion or metastasis $(19,20)$. There are many molecular targets that are up-regulated by Wnt signal transduction, for example, c-myc (21), cyclin-D (22), uPA receptor (23), CD-44 (24), and COX-2 (25); matrilysin is also considered to be one such target (26).

Matrilysin and stromelysin-1 have been shown to cleave E-cadherin on the surface of MCF-7, a breast cancer cell line, and produce a soluble fragment of E-cadherin (27). This process resulted in an invasive potential in MCF-7 cells independent of proteinases. Moreover, recombinant human matrilysin cleaved E-cadherin on the surface of a prostate cancer cell line, and caused an increase in unbound or free pools of beta catenin within the cytoplasm as a result of its dissociation from the E-cadherin/catenin complex (28). In immunohistochemical studies of colorectal cancer, it was shown that expression of matrilysin (29) or stromlysin-3 (30) in cancer cells led to an under-expression of E-cadherin and an abnormal expression of beta-catenin. Nuclear expression of beta-catenin is likely to be related to the activation of the Tcf DNA binding protein.

In our studies, matrilysin stimulated proliferation of HUVECs in the low serum conditioned medium. VE-cadherin expression decreased in cells stimulated with matrilysin and the expression was unchanged in control cells (Fig. 1). Moreover, a smaller fragment reacting to VE-cadherin antibody was detected in the culture medium of HUVECs. The smaller fragment could not be detected in the culture medium of HUVECs without stimulation of matrilysin.
So matrilysin had to cleave VE-cadherin on the cell membrane of the HUVEC.

In HUVECs that showed down-regulation of VEcadherin, beta-catenin was located in the nucleus, whereas in the control cells that retained VE-cadherin expression, it was located in the cytoplasm. From these results we hypothesize that matrilysin degrades VE-cadherin and increases the free pool of beta-catenin in the cytoplasm; beta-catenin is then transported into the nucleus. Interestingly, there was an increase in matrilysin mRNA expression in HUVECs that were stimulated with matrilysin, and this was regulated by the Tcf-4 DNA binding protein (26); matrilysin was not expressed in control HUVECs. This was compelling evidence that matrilysin stimulation activated Tcf DNA transcription through an increase of free beta-catenin in the cytoplasm. We had previously reported that newly formed blood vessels around tumors secreting matrilysin expressed matrilysin mRNA (31). These observations may also be explained by the results of our experiment described here. Moreover, COX-2 mRNA, which is also promoted by Tcf-4, was up-regulated by matrilysin stimulation. This was collateral evidence of activation of Tcf- 4 by matrilysin. Matrilysin also has another role for angiogenesis in some reports. Matrilysin cleaves plasminogen and converts it to angiostatin (32), which is one of the strong inhibitors of angiogenesis. So, matrilysin might indirectly have the ability to inhibit tumor angiogenesis. Tumor angiogenesis must be regulated by matrilysin through a complex mechanism.

Matrilysin plays important roles in angiogenesis, and may be an important target for anti-cancer therapy. In light of this it is important to further examine the mechanism whereby matrilysin regulates angiogenesis.

\section{References}

1. Ishikawa T, Ichikawa Y, Mitsuhashi M, Momiyama N, Chishima T, Tanaka K, Yamaoka H, Miyazaki K, Nakashima Y, Akitaya $\mathrm{T}$ and Shimada $\mathrm{H}$ : Matrilysin is associated with progression of colorectal tumor. Cancer Lett 107: 5-10, 1996.

2. Momiyama N, Koshikawa, N Ishikawa, et al: Inhibitory effect of matrilysin antisense phosphorothioate oligonucleotides on human colon cancer cell invasion in vitro. Mol Carcinog 22: 57-63, 1998.

3. Hasegawa S, Koshikawa N, Momiyama N, Momiyama K, Ichikawa Y, Ishikawa T, Mitsuhashi M and Shimada H: Matrilysin-specific antisense oligonucleotide inhibits liver metastasis of human colon cancer cells in a nude mouse model. Int J Cancer 76: 812-816, 1998.

4. Huo N, Ichikawa Y, Kamiyama M, Ishikawa T, Hamaguchi Y, Hasegawa S, Nagashima Y, Miyazaki K and Shimada H: MMP-7 (matrilysin) accelerated growth of Human umbilical vein endothelial cells (HUVEC). Cancer Lett 177: 95-100, 2002.

5. Nishizuka I, Ichikawa Y, Ishikawa T, Kamiyama M, Hasegawa S, Momiyama N, Miyazaki K and Shimada H: Matrilysin stimulates DNA synthesis of cultured vascular endothelial cells and induces angiogenesis in vivo. Cancer Lett 173: 175-182, 2001.

6. Huang S, Van Arsdall M, Tedjarati S, McCarty M, Wu W, Langley R and Fidler IJ: Contributions of stromal metalloproteinase-9 to angiogenesis and growth of human ovarian carcinoma in mice. J Natl Cancer Inst 94: 1134-1142, 2002.

7. Bajou K, Lewalle JM, Martinez CR, Soria C, Lu H, Noel A and Foidart JM: Human breast adenocarcinoma cell lines promote angiogenesis by providing cells with uPA-PAI- 1 and by enhancing their expression. Int J Cancer 100: 501-506, 2002.

8. Wylie S, MacDonald IC, Varghese HJ, Schmidt EE, Morris VL, Groom AC and Chambers AF: The matrix metalloproteinase inhibitor batimastat inhibits angiogenesis in liver metastases of B16F1 melanoma cells. Clin Exp Metastasis 17: 111-117, 1999. 
9. Yazama F, Kadonosono K, Itoh $\mathrm{N}$ and Ohno S: Role of matrix metalloproteinase-7 in angiogenesis associated with age-related macular degeneration. J Electron Microsc 51: 127-131, 2002.

10. Di Girolamo N, Coroneo MT and Wakefield D: Active matrilysin (MMP-7) in human pterygia: potential role in angiogenesis. Invest Ophthalmol Vis Sci 42: 1963-1968, 2001.

11. Sang QX: Complex role of matrix metalloproteinases in angiogenesis. Cell Res 8: 171-177, 1998.

12. Hiraok N, Allen E, Apel IJ, Gyetko MR and Weiss SJ: Matrix metalloproteinases regulate neovascularization by acting pericellular fibrinolysins. Cell 95: 365-377, 1998.

13. Chambers AF and Matrisian LM: Changing views of the role of matrix metallo proteinases in metastasis. J Natl Cancer Inst 89: 1260-1270, 1997.

14. Hashimoto G, Inoki I, Fujii Y, Aoki T, Ikeda E and Okada Y: Matrix metalloproteinases cleave connective tissue growth factor and reactivate angiogenic activity of vascular endothelial growth factor 165. J Biol Chem 277: 36288-36295, 1995.

15. Milia AF, Salis MB, Stacca T, Pinna A, Madeddu P, Trevisani M, Geppetti $\mathrm{P}$ and Emanueli C: Protease-activated receptor-2 stimulates angiogenesis and accelerates hemodynamic recovery in a mouse model of hindlimb ischemia. Circ Res 91: 346-352, 2002.

16. Caveda L, Martin-Padura I, Navarro P, Breviario F, Corada M, Gulino D, Lampugnani MG and Dejana E: Inhibition of cultured cell growth by vascular endothelial cadherin (cadherin5/VE-cadherin). J Clin Invest 98: 886-893, 1996.

17. Wright M, Aikawa M, Szeto W and Papkoff J: Identification of a Wnt-responsive signal transduction pathway in primary endothelial cells. Biochem Biophys Res Commun 263: 384-388, 1999.

18. Oving IM and Clevers HC: Molecular causes of colon cancer. Eur J Clin Invest 32: 448-457, 2002.

19. Brabletz T, Jung A, Dag S, Reu S and Kirchner T: Beta-Catenin induces invasive growth by activating matrix metalloproteinases in colorectal carcinoma. Verh Dtsch Ges Pathol 84: 175-181, 2000.

20. Chiang JM, Chou YH, Chen TC, Ng KF and Lin JL: Nuclear beta-catenin expression is closely related to ulcerative growth of colorectal carcinoma. Br J Cancer 86: 1124-1129, 2002.

21. He TC, Sparks AB, Rago C, Hermeking H, Zawel L, Da Costa LT, Morin PJ, Vogelstein B and Kinzler KW: Identification of c-MYC as a target of the APC pathway. Science 281: 1438-1411, 1998.

22. Tetsu O and McCormick F: Beta-catenin regulates expression of cyclin D1 in colon carcinoma cells. Nature 398: 422-426, 1999.
23. Wielenga VJ, Smits R, Korinek V, Smit L, Kielman M, Fodde R, Clevers H and Pals ST: Expression of CD44 in Apc and Tcf mutant mice implies regulation by the WNT pathway. Am J Pathol 154: 515-523, 1999.

24. Mann B, Gelos M, Siedow A, Hanski ML, Gratchev A, Ilyas M, Bodmer WF, Moyer MP, Riecken EO, Buhr HJ and Hanski C: Target genes of beta-catenin-T cell-factor/lymphoid-enhancerfactor signaling in human colorectal carcinomas. Proc Natl Acad Sci USA 96: 1603-1608, 1999.

25. Haertel-Wiesmann M, Liang Y, Fantl WJ and Williams LT: Regulation of cyclooxygenase- 2 and periostin by Wnt-3 in mouse mammary epithelial cells. J Biol Chem 275: 32046-32051, 2000.

26. Crawford HC, Fingleton BM, Rudolph-Owen LA, Goss KJ, Rubinfeld B, Polakis P and Matrisian LM: The metalloproteinase matrilysin is a target of beta-catenin transactivation in intestinal tumors. Oncogene 18: 2883-2891, 1999.

27. Noe V, Fingleton B, Jacobs K, Crawford HC, Vermeulen S, Steelant W, Bruyneel E, Matrisian LM and Mareel M: Release of an invasion promoter E-cadherin fragment by matrilysin and stromelysin-1. J Cell Sci 114: 111-118, 2001.

28. Davies G, Jiang WG and Mason MD: Matrilysin mediates extracellular cleavage of E-cadherin from prostate cancer cells: a key mechanism in hepatocyte growth factor/scatter factorinduced cell-cell dissociation and in vitro invasion. Clin Cancer Res 7: 3289-3297, 2001.

29. Ougolkov AV, Yamashita K, Mai M and Minamoto T: Oncogenic beta-catenin and MMP-7 (matrilysin) cosegregate in late-stage clinical colon cancer. Gastroenterology 122: 60-71, 2002 .

30. Wlodarczyk J, Stolte M and Mueller J: E-cadherin, beta-catenin and stromelysin-3 expression in de novo carcinoma of the colorectum. Pol J Pathol 52: 119-124, 2001.

31. Nagashima Y, Hasegawa S, Koshikawa N, Taki A, Ichikawa Y, Kitamura H, Misugi K, Kihira Y, Matuo Y, Yasumitsu H and Miyazaki K: Expression of matrilysin in vascular endothelial cells adjacent to matrilysin-producing tumors. Int J Cancer 72: 441-445, 1997.

32. Patterson BC and Sang QA: Angiostatin-converting enzyme activities of human matrilysin (MMP-7) and gelatinase B/type IV collagenase (MMP-9). J Biol Chem 272: 28823-28825, 1997. 